\title{
Research on the Development Strategy of Domestic Airline Market under "The Belt and Road"
}

\author{
Xiaoshuo Zhao \\ SANYA Aviation and Tourism College, Sanya, Hainan Province, China, 572000
}

Keywords: Belt and Road Initiative; Strategy; Aviation; Cooperation; Airlines

\begin{abstract}
Belt and Road Initiative along including a total of 65 countries (including China), along the country's total population of about 4 billion 400 million, accounting for the world's total population of $60 \%$, GDP accounted for about $30 \%$ of the world. Civil aviation is an important link in the development of bilateral or multilateral relations, and is the "first force" of the state's opening to the outside world. With the implementation and promotion of the development strategy of The Belt and Road ", the national opening pattern will show a new situation, in the analysis of the current situation on the basis of the quantitative analysis method and analysis of China's" The Belt and Road countries along bilateral economic and civil aviation development foundation, weak problem, how to the aviation industry to better implement the "The Belt and Road" strategy conducted in-depth research, and gives suggestions for the development
\end{abstract}

\section{Introduction}

\section{1. development status of civil aviation industry in China}

As the world's second largest economy, the first largest exporter, the second largest importer, the third largest foreign investor and the largest tourist source country, the rapid development of China's national economy has increased demand for civil aviation. The scale of air transportation in China has been second in the world. It is next only to the US. Its position on the international stage has gradually changed from the past active followers to the important participants.

By the end of 2015, China had 206 civil airports, including 69 open the airport has been opened to the 138 city all over the world 56 countries and regions of the flight; civil aviation industry annual passenger traffic 440 million passengers, cargo transport volume of 6 million 300 thousand tons, an increase of $11.4 \%$ and $6 \%$ respectively, which are passenger volume proportion of passenger volume is about 10\%; the airport of Hongkong, capital of Beijing, Guangdong and Shanghai four Pudong Baiyun Airport as a major domestic and international aviation hub, to undertake the transfer of about 32\% Chinese international travelers.

\section{2. "The Belt and Road" along the national development situation}

"The Belt and Road" along the national economic development and the development of civil aviation at different levels, as shown in table 1. Among them, in terms of economic development, the national area of Mongolia and Russia and East Europe and West Asia and North Africa, the average economic development level is good; and the CIS countries in Central Asia, Southeast Asia and other regions with similar economic development level China; the level of national economic development in South Asia is relatively backward, but a large population, with great potential for development. In terms of civil aviation development, the average level of civil aviation development in West Asia and North Africa is generally more mature than that in Mongolia and Russia. The development of civil aviation is lagging behind in Southeast Asia, central and Eastern Europe, and Central Asia, the Commonwealth of Independent States and South Asia. 
Table 1 overview of economic and aviation development in countries

\begin{tabular}{cccccc}
\hline & & & & \multicolumn{2}{c}{$\begin{array}{c}\text { Civil aviation contact with our } \\
\text { country }\end{array}$} \\
\cline { 6 - 7 } region & $\begin{array}{c}\text { Number of } \\
\text { States }\end{array}$ & $\begin{array}{c}\text { Per capita GDP, } \\
\text { US dollar }\end{array}$ & $\begin{array}{c}\text { Per capita } \\
\text { number of times }\end{array}$ & $\begin{array}{c}\text { Already } \\
\text { navigable } \\
\text { Number of } \\
\text { states } *\end{array}$ & $\begin{array}{c}\text { Unsigned } \\
\text { navigation right } \\
\text { National number }\end{array}$ \\
\hline Southeast Asia & 11 & 3785.3 & 0.38 & 10 & 1 \\
\hline $\begin{array}{c}\text { West Asia and } \\
\text { North Africa }\end{array}$ & 16 & 9850.5 & 0.57 & 8 & 3 \\
\hline South Asia & 8 & 1389.4 & 0.05 & 6 & 0 \\
\hline $\begin{array}{c}\text { Mongolia and } \\
\text { Russia }\end{array}$ & 2 & 13838.9 & 0.41 & 2 & 0 \\
\hline $\begin{array}{c}\text { Central Asia } \\
\text { Central and }\end{array}$ & 5 & 4591.0 & 0.13 & 5 & 2 \\
\hline Eastern Europe & 16 & 11404.7 & 0.27 & 4 & 0 \\
\hline CIS & 6 & 4506.5 & 0.12 & 3 & 0 \\
\hline
\end{tabular}

Since joining the WTO, China and The Belt and Road along the country's trade is growing rapidly. Among them, China's trade links with Southeast Asian countries are most closely related, as shown in Figure 1. The 11 Southeast Asian countries and China total trade accounted for Belt and Road Initiative state and Chinese trade volume of about $44 \%$, mainly because the Southeast Asian countries as a priority direction Chinese surrounding foreign countries, good relations, contribute to the promotion of bilateral trade, the establishment of China ASEAN free trade area is greatly enhanced and China trade relations in Southeast Asian countries. The proportion of the total trade of Western Asia and North Africa and China is $28 \%$, which is the second place. With the China total trade is the fastest growing countries in Central Asia, due to the small base, nearly ten years the average annual growth rate of nearly 30\%, higher than the same period China and The Belt and Road "countries along the trade volume of the average annual growth rate of $22 \%$.

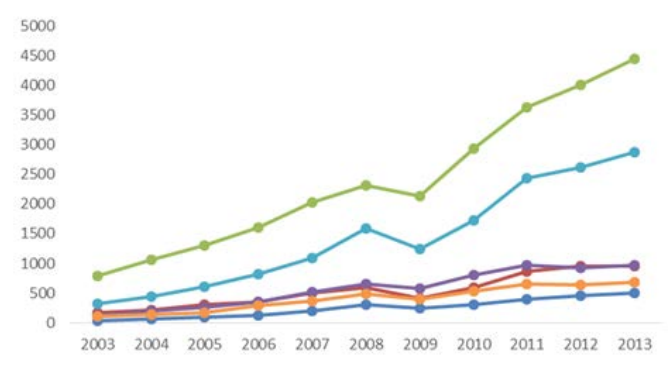

The national total trade figure 1 Chinese and The Belt and Road along regional (trillion yuan)

As of 2015, 57 in China has along with the "The Belt and Road" 64 countries signed a bilateral intergovernmental agreement on air transport, and of which 38 countries achieve regular navigation. The proportion of the number of countries that have been navigable accounts for nearly $60 \%$ of the total number of countries along the route, and the total number of navigation countries accounts for $94.6 \%$ of the total population of the countries along the line. GDP accounts for $90.9 \%$ of the total GDP of the countries along the line. In 2014, the total number of international air passenger transport between countries and China along the line was about 26 million 200 thousand.

From the market scale of international air transport between China and other countries, is the largest market in Southeast Asia International Aviation "The Belt and Road along China's market share is as high as 73.5\%; followed by South Asia, West Asia and North Africa, Mongolia and 
Russia and other regions or countries; Central Asia, Eastern Europe and the CIS countries in the international aviation market development is still relatively weak, needs to be strengthened in terms of civil aviation.

\section{Existing problems}

At present, the following main problems associated with the development of China's civil aviation and The Belt and Road countries along in:

\subsection{The agreement between China and some countries has not yet been signed}

Between the more than 20 countries and traffic rights are not fully used, not navigable or less flights, international route network coverage is inadequate; and some countries need to further expand the amount of traffic rights, capacity has been inadequate, especially in South Asia, Central Asia and other regions of the country; the political environment in some countries is not very stable, further cooperation effect of regional air transportation development and with China's civil aviation.

\subsection{China has not yet formed effectively, "The Belt and Road" strategic international hub airport layout.}

One is the domestic has not yet formed a reasonable international airport echelon, in addition to three wide north international hub, hub airports were not formed with other international route network targeted and certain scale. The two is foreign to China hub airport serious international transit passenger flow diversion, leading to the market "The Belt and Road along the country in China's international transfer in China hub airport in Southeast Asia, South Asia, Central Asia, Russia and Mongolia areas close to the international market to occupy obvious advantages, but in Europe and the Middle East West Asia and North Africa, the CIS and other areas of the international market does not have the advantage of hub. In 2011, only four foreign hub airports, such as Dubai, Frankfurt, Inchon and Amsterdam, have diverted about 20\% of the international transit passenger flow in our country.

Our country has not yet built an effective cooperative mechanism of civil aviation comprehensive cooperation. The capacity of domestic air transportation, airport and air traffic control, industry consultation, education and training has not yet been fully developed.

\section{Development strategies and suggestions}

In accordance with the "core value concept of The Belt and Road" strategy of "peaceful cooperation, openness and tolerance, mutual learning, mutual benefit and win-win" and realize the policy exchange, facilities Unicom, trade flow, financing requirements, the people connected with the strategic objectives, combined with the development of China's Civil Aviation industry and economic situation along the national civil aviation the actual development, put forward relevant policy suggestions:

\subsection{Speed up the construction of infrastructure and improve the security of Civil Aviation}

One is based on "The Belt and Road" construction, accelerate the improvement of the airport layout, accelerate the construction of the new airport in Chengdu, Beijing, Beijing and Tianjin Hebei, Yangtze River Delta and other areas of the airport group collaborative development, enhance the overall efficiency of the airport group and international competitiveness, enhance the ability to protect the key airport. The two is to promote the upgrading and upgrading of the air pipe infrastructure along the line, enhance the ground security capacity of the civil aviation, and promote the docking mechanism of the border air pipe infrastructure. Three is to optimize and improve the airport collection and distribution system construction, fast and convenient mass public transportation network construction between the airport and the city center to strengthen and promote civil aviation and other transport modes in the service standards system interoperability, promote large-scale airport multimodal transport development. 


\subsection{Improve the capacity of air transport service and build a large air transport channel}

The first is to speed up the negotiation of the air rights, expand the air power, and lay the foundation for the opening and extending of the large air passage in advance. The two is the first to build air transportation channels, increase the number of air silk road route, new international routes, improve the utilization rate of traffic rights, increase the international shipping point, expanded air service coverage, improve the accessibility of The Belt and Road air channel network. The three is to increase the input The Belt and Road "route capacity, to encourage domestic airlines to make full use of traffic rights, to open up" The Belt and Road "new international routes, more capacity, optimizing the flight routes, improve aviation transportation service level, improve the patency of The Belt and Road air channel. The four is to develop "The Belt and Road international aviation hub, Beijing, Shanghai, Guangzhou to strengthen the three major international hub, construction of the main channels Unicom International and domestic political, financial and economic center, targeted to guide Urumqi, Harbin, Fuzhou, Kunming airport is facing" The Belt and Road "regional international aviation hub, and at the same time to strengthen the radiation ability of the hub airport route network in china. The five is to promote the establishment of the Silk Road "airline alliance", or through the airline alliance code sharing international route network and aviation service of China Airlines extended to The Belt and Road "in various regions and countries more city.

\subsection{Promote enterprise "go out"}

One is to accelerate the air transport service to go out, the international air transport market to encourage domestic airlines more into the "The Belt and Road" countries, to improve China's competitiveness of airlines on international routes on the market, to promote products and services to other industries is more fast and convenient to go out, to provide convenient, efficient and high-quality air transport service for business between China and other countries and tourism exchanges. Two, we should actively develop overseas civil aviation infrastructure investment projects, encourage and guide all kinds of social capital and state-owned enterprises to participate in the development, investment, construction and operation of civil aviation infrastructure projects at home and abroad, and broaden the financing channels for all kinds of projects. The three is to encourage civil aviation industry and related industry of all kinds of services and products packaged to go out and accelerate the domestic civil aircraft products such as the pace of developing international market. The four is to strengthen the communication technology and the humanities, to support domestic aviation related businesses and educational institutions held key international conference and demonstration of foreign training cooperation projects The Belt and Road "area, guide and encourage domestic enterprises and institutions and foreign joint education.

\section{Conclusion}

One is to build a comprehensive cooperation mechanism for civil aviation. To establish and perfect the basic coordination mechanism of civil aviation and related departments, enterprises, and speed up between countries signed bilateral aviation agreement and airworthiness agreement; and established between countries include civil aviation infrastructure construction investment, operation management, complete supporting products procurement service output, investment enterprise registration, personnel training, technical exchanges civil aviation multi-level, all-round cooperation platform and mechanism; establishing and perfecting the legal framework of bilateral and multilateral cooperation in civil aviation, and guide domestic enterprises to avoid investment risk and reasonable response; build government and government, between government and enterprises, between the enterprise and the enterprise information communication platform, improve the policy of government affairs, all kinds of symmetric information query help, full docking programs and policies, projects and funding, projects and talents. The allocation of funds tend to moderate "The Belt and Road" opening, middle and small type airport airport construction project; improved route subsidy policies to encourage airlines and airports to cultivate and construct the "The Belt and Road" international route network, encourage and guide the development of small 
and medium-sized airport route; improve small airport operating subsidy policy, the appropriate allocation of funds tend to small and medium sized airports in central and western regions; the two is to give full play to the guiding role of civil aviation subsidy policy. Improve the airport investment subsidy policy, in considering "The Belt and Road special financial subsidy funds, for the initial loss of domestic enterprises to invest in the" The Belt and Road "national civil aviation project management and overseas financial subsidies to moderate or low interest loans to support, to help enterprises through the initial difficulties and achieve sustainable development. The three is to establish and improve the financial support system. Make full use of the investment bank, the Silk Road Fund, BRIC banks and other financial institutions at home and abroad and the feasible platform to provide financing support for "The Belt and Road" aviation project. We should coordinate various financial platforms and provide financial services and financial support for our airline enterprises in overseas aviation industry through loan, credit and financial leasing. The four is to strengthen the implementation of the organization. The government suggested the establishment of coordination mechanism, and external two aspects, to promote research related work, tracking, communication and implementation of the "civil aviation to solve the new situation and new problems The Belt and Road" strategy in the work.

\section{Reference}

[1] Jennifer W. Chan, Yingyue Zhang, and Kathryn E. Uhrich, Amphiphilic Macromolecule Self-Assembled Monolayers Suppress Smooth Muscle Cell Proliferation, Bioconjugate Chemistry, 2015, 26(7), 1359-1369.

[2] Yingyue Zhang, Evan Mintzer, and Kathryn E. Uhrich, Synthesis and Characterization of PEGylated Bolaamphiphiles with Enhanced Retention in Liposomes, Journal of Colloid and Interface Science, 2016, 482, 19-26.

[3] Jonathan J. Faig, Alysha Moretti, Laurie B. Joseph, Yingyue Zhang, Mary Joy Nova, Kervin Smith, and Kathryn E. Uhrich, Biodegradable Kojic Acid-Based Polymers: Controlled Delivery of Bioactives for Melanogenesis Inhibition, Biomacromolecules, 2017, 18(2), 363-373.

[4] Lv, Z., Halawani, A., Feng, S., Li, H., \& Réhman, S. U. (2014). Multimodal hand and foot gesture interaction for handheld devices. ACM Transactions on Multimedia Computing, Communications, and Applications (TOMM), 11(1s), 10. 